\title{
A MOdel to AdOPT Enterprise Resource Planning (ERP) AND BUSINESS INTELLIGENCE (BI) AMONG SAUDI SMES
}

\author{
UM MODELO PARA ADOTAR O ENTERPRISE RESOURCE PLANNING (ERP) E BUSINESS \\ INTELLIGENCE (BI) ENTRE AS PMES SAUDITAS \\ UN MODELO PARA ADOPTAR LA ENTERPRISE RESOURCE PLANNING (ERP) Y BUSINESS \\ INTELLIGENCE (BI) ENTRE LAS PYMES SAUDITAS
}

Showaimy Aldossari ${ }^{1}$

Umi Asma Mokhtar ${ }^{2}$

\section{Cite as - American Psychological Association (APA)}

Aldossari, S., \& Mokhtar, U. A. (2020, May/Aug.). A model to adopt Enterprise Resource Planning (ERP) and Business Intelligence (BI) among saudi SMEs. International Journal of Innovation - IJI, São Paulo, 8(2), 305347. https://doi.org/10.5585/iji.v8i2.17395.

\begin{abstract}
Objective of the study: This paper touched upon the major issues that are related to intention towards the use of ERPBI in the Saudi private sector - Saudi Arabia is an example of a developing country

Methodology / approach: This paper used a qualitative approach and the sample of the study comprised of 30 experts from the Saudi private sector, who were involved in ERPBI.

Originality / Relevance: According to prior studies in literature, there is no specific model that supports and explains ERPBI, and as such, this increases the chances of ineffective adoption and use of ERPBI. This study found that ERPBI adoption models are lacking, and those that exist are inapplicable as they exclude several significant factors for successful adoption.

Main results: The findings indicated that for the promotion of the ERPBI model, the entire significant factors have to be considered and incorporated. Those factors are: system quality, service quality, and information quality factors, change management, effective communication, training factors, clear vision and planning, competitive pressure, and government role.

Theoretical / methodological contributions: This study's results open door for future research based on the gap in theories applied and the factors investigated in the context of developing nations.
\end{abstract}

Social / management contributions: Shedding light on the factors and their relationship with ERPBI use success would assist top management in minimizing losses through system use for enhanced cash flow, and improved performance of employees and that can eventually bring about the overall performance of the organization.

Keywords: Enterprise Resource Planning (ERP). Business Intelligence (BI). Model. Saudi Arabia. Adoption. Organizational performance.

\footnotetext{
${ }^{1}$ Universiti Kebangsaan Malaysia, Bangi, Selangor - Malaysia. ceo@tania.sa

${ }^{2}$ Universiti Kebangsaan Malaysia, Bangi, Selangor - Malaysia. umimokhtar@ukm.edu.my
} 


\section{Resumo}

Objetivo do estudo: Este artigo abordou as principais questões relacionadas à intenção de uso de ERPBI no setor privado saudita - a Arábia Saudita é um exemplo de país em desenvolvimento

Metodologia / abordagem: Este trabalho utilizou uma abordagem qualitativa e a amostra do estudo foi composta por 30 especialistas do setor privado saudita, envolvidos no ERPBI.

Originalidade / Relevância: De acordo com estudos anteriores na literatura, não existe um modelo específico que suporte e explique o ERPBI e, como tal, aumenta as chances de adoção e uso ineficaz do ERPBI. Este estudo constatou que faltam modelos de adoção do ERPBI e os que existem são inaplicáveis, pois excluem vários fatores significativos para uma adoção bemsucedida.

Principais resultados: Os resultados indicaram que para a promoção do modelo ERPBI, todos os fatores significativos devem ser considerados e incorporados. Esses fatores são: qualidade do sistema, qualidade do serviço e fatores da qualidade da informação, gerenciamento de mudanças, comunicação eficaz, fatores de treinamento, visão e planejamento claros, pressão competitiva e papel do governo.

Contribuições teórico-metodológicas: Os resultados deste estudo abrem portas para pesquisas futuras baseadas na lacuna das teorias aplicadas e dos fatores investigados no contexto das nações em desenvolvimento.

Contribuições sociais / gerenciais: esclarecer os fatores e sua relação com o sucesso do uso do ERPBI ajudaria a alta administração a minimizar as perdas por meio do uso do sistema para aumentar o fluxo de caixa e melhorar o desempenho dos funcionários, o que pode eventualmente influenciar o desempenho geral da organização.

Palavras-chave: Enterprise Resource Planning (ERP). Business Intelligence (BI). Modelo. Arábia Saudita. Adoção. Desempenho organizacional.

\section{Resumen}

Objetivo del estudio: Este artículo abordó los principales problemas relacionados con la intención de utilizar ERPBI en el sector privado saudí: Arabia Saudita es un ejemplo de país en desarrollo.

Metodología / enfoque: Este artículo utilizó un enfoque cualitativo y la muestra del estudio fue compuesta por 30 expertos del sector privado saudí, que participaron del ERPBI.

Originalidad / Relevancia: Según estudios previos en la literatura, no existe un modelo específico que respalde y explique el ERPBI y, como tal, esto aumenta las posibilidades de adopción y uso ineficaz del ERPBI. Este estudio identificó que faltan modelos de adopción de ERPBI, y los que existen son inaplicables ya que excluyen varios factores importantes para una adopción exitosa.

Resultados principales: Los hallazgos del estudio indicaron que para la promoción del modelo ERPBI, se deben considerar e incorporar todos los factores significativos. Esos factores son: calidad del sistema, calidad del servicio y factores de calidad de la información, gestión del cambio, comunicación eficaz, factores de capacitación, visión y planificación claras, presión competitiva y papel del gobierno.

Contribuciones teóricas / metodológicas: Los resultados de este estudio abren la puerta para futuras investigaciones basadas en la brecha de las teorías aplicadas y los factores investigados en el contexto de las naciones en desarrollo.

Contribuciones sociales / de gestión: Aclarar los factores y su relación con el éxito del uso del ERPBI ayudará a la alta dirección a minimizar las pérdidas a través del uso del sistema para aumentar el flujo de caja y mejorar el desempeño de los empleados, lo que eventualmente puede influir en el desempeño general de la organización. 
Palabras clave: Planificación de recursos empresariales (EpRP). Inteligencia empresarial (BI). Modelo. Arabia Saudita. Adopción. Desempeño organizacional.

\section{Introduction}

In the present dynamic business marketplace, complexity, and environment shift (from place to space) along with economic globalization and information technology development have changed the business landscape. As a consequence, market competition has been enhanced, and competition increases daily (Gazem \& Rahman, 2015; Celina M Olszak \& Ziemba, 2012).

In addition, ICT has promoted the spread of services globalization and technology development as a result of which service companies have to constantly offer new products/services to maintain their competitiveness (Ram, Corkindale, \& Wu, 2013). As such, most organizations have intensified their investments in varying systems of IT (Mukred \& Yusof, 2015, 2018), and such systems include ERP (Erp, Gevers, Rispens, \& Demerouti, 2018) and BI (Rouhani (Rouhani \& Lecic, 2018).

In relation to the above, majority of ERP systems require an integrated BI system for accounting and transaction management, and this consists of inventory, material needs, or capacity planning. Nevertheless, owing to the lack of reporting capabilities in the system, most firms have to use spreadsheets for their planning and management operations (Helmy, Marie, \& Mosaad, 2012). Therefore, the combination the use between ERP and BI, rather than their individual use is more feasible (Ince, Imamoglu, Keskin, Akgun, \& Efe, 2013) as this has shown to enhance the performance of the organizations' capabilities in many studies (e.g., (Albu, Albu, Dumitru, \& Dumitru, 2015; Chen, Chiang, \& Storey, 2012; Richards, Yeoh, Chong, \& Popovič, 2017; Rouhani \& Lecic, 2018; Saleh \& Thoumy, 2018; Yeoh \& Popovič, 2016)). More specifically, an integrated ERPBI, commonly referred to as ERPBI, has the capability of providing additional features, functionalities, and flexibility through the sharing of information (Helmy et al., 2012). In fact, the ERPBI usage allows management to shed light on the data processes and arrangement in an attempt to access real-time operational information and to produce accurate reports to enhance decision-making and ultimately, the overall performance of the organizations (C. M. Olszak \& Ziemba, 2007; Ziemba, 2013).

In businesses, adopting technology can generally lead to the enhanced performance of the overall organization (Mukred, M Yusof, Mokhtar, \& Abdul Manap, 2016; Mukred \& Yusof, 2017). In this regard, effective usage of ERPBI must be promoted in businesses for success as 
its ineffective usage often leads to failure. In relation to this, studies have already investigated the determinants of successful ERPBI use, but most of the studies overlooked the determination of the drivers of organizational performance. According to (Heinrich, Merkle, Henss, \& Paech, 2017), some studies like that of (NJERI, 2013) indicated that ERPBI systems fail in running multidimensional processes. Experts have also recommended the use of ERPBI to improve decision making, customer relationships, and reporting and these call for adoption among organizations to enhance their capabilities of decision-making and eventually, their whole performance (Aldossari \& Mukhtar, 2018; Heinrich et al., 2017; ISLAM NOFAL \& YUSOF, 2016; Kasemsap, 2017; Nofal \& Yusof, 2013).

Based on the above background, there is a need to understand the drivers of ERPBI behavioral intention to use, particularly in the context of the developing nation, to ensure the effective utilization of IT resources (Ince et al., 2013). In literature, only a few researchers have made examinations of the integration of ERP with BI in the developing nations' contexts, specifically Saudi Arabia. Therefore, such examination can benefit Saudi Arabia and developing nations in light of the adoption of the ERPBI system, assist in making decisions in creating accurate and effective ERPBI strategies, and help the facilitation of products/service design among suppliers and software designers in order to satisfy the end-users requirements.

Moreover, such examination of factors and their role in the ERPBI use and adoption success would facilitate management's mitigation of organizational losses as the system offers solutions including cash flow enhancement, controlling expenses, headcount management and performance of employees, and it also streamlines spend and supply chain operations, keeps abreast of financial performance in terms of key projects and improves customer relationships and systems of reporting (Rajan \& Baral, 2015). The highlighted factors can be used to achieving optimum success potential, with management focusing on oversight, control, and support of significant areas of business. In terms of senior management, the findings of this paper can assist in directing limited resources to the key areas that could work towards the enhancement of behavioral intention to use ERPBI, and eventually, the improvement of the system adoption process.

As for the paper's practical contributions, through the findings, SMEs will be more capable of identifying the factors to contribute to the success chances, and such factors should ensure the reception of ongoing management control. The findings can also help senior management to optimize their limited resources and direct them to major areas that could enhance the process of using the system. 
Hawking and Sellitto (2017), Almajali, Masa'deh, and Tarhini (2016), Chaudhry, Iffat, and Safdar (2016) and Khan, Awan, and Ho (2018) highlighted the rate of ERPBI implementation failure in developing nations according to the absence of frameworks. This was the reason also that led to S. Ahmad, Ibrahim, and Garba (2015) suggestion for more research to be dedicated to ERPBI, particularly focusing on the drivers of its adoption. Similarly, researchers indicated the inappropriateness of attributing the success/failure of the ERPBI project to technical issues, as this may also stem from the way the software is implemented. Nevertheless, owing to the lack of knowledge and experience regarding the relevant factors, there is a tendency among organizations to underestimate the needs of its personnel and the firm itself that negatively impacts successful ERPBI use (Hawking \& Sellitto, 2017; Mahmood \& Mann, 1993; Singh, Singh, \& Kaur, 2017). Hence, more empirical studies are needed to examine the factors that impact such adoption. According to (Ram et al., 2013; Ram, Wu, \& Tagg, 2014), $20 \%$ of the identification of the factors could largely impact (80\%) the performance of the organization. It is crucial to understanding the factors driving ERPBI use, specifically in the context of developing countries to guarantee that the IT resources are effectively utilized. Nevertheless, only a few authors have examined ERPBI integration in developing nations, particularly in Saudi Arabia. Such an understanding of ERPBI principles would benefit developing countries, with the inclusion of software suppliers. It would also benefit major decision-makers in designing more effective ERPBI strategies, and software designers and suppliers to facilitate products/services design that meets the requirements of end-users

For easy clarification and flow, the present paper is organized the following way; first, the review of works dedicated to ERPB and BI in the developing nations is presented. The study then presents the methodology and the proposed ERPBI model. The implication of the study is presented thereafter, and lastly, the results are presented and discussed and the conclusion provided.

\section{Related Works}

In relation to Enterprise Resource Planning and Business Intelligence (ERPBI), it should be noted that it is not a simple piece of computer software owing to its ability to transform the business process. An increasing number of organizations and industries are adopting the system, and the majority of them have displayed enhanced performance by using ERP and BI in light of their human resource planning, management control, and operational control. 
Currently, researchers are of the consensus with regards to the potential promise that ERP holds in the Small and Medium Enterprises (SME), with the combination of both systems (ERPBI) successful in bringing about core competency in the majority of firms (Bhattacharya, Wamba, \& Kamdjoug, 2019; Chan, Abu-Khadra, \& Alramahi, 2011; Yusof, Ab Aziz, Shatat, \& Saleh, 2013).

This section provides an all-encompassing review of relevant works in prior literature concerning integrated ERP and BI. The ERP and BI implementation call for bringing forth an integrated ERPBI model, and accordingly, it is pertinent to obtain insights into the significant factors to proceed with the development of an integrated ERPBI system in an organizational setting in order to enhance the performance of organizations.

\section{Definition of Enterprise Resource Planning and Business Intelligence (ERPBI)}

Notably, ERPBI is not just a simple computer software component, as it is capable of transforming business processes in organizations based on modules. An increase in the ERPBI adoption among organizations has been evidenced with their consequential enhanced performance, particularly when it comes to human resource planning, management control, and operational control. Researchers are unanimous in the provision of ERP and the BI of potential firm competency (e.g., (Chan et al., 2011; Yusof et al., 2013)).

ERP is described as a software package that integrates the entire firm departments and functions into a computer system that has the capability of serving the needs of departments (Fanning \& Centers, 2013; Jinno, Abe, \& Iizuka, 2017). Business intelligence (BI) refers to a system that analyzes business information to reinforce and enhance the management decision making throughout different business activities, and to leverage significant data infrastructure investments (Elbashir, Collier, \& Davern, 2008).

In this background, Goni, Chofreh, Mukhtar, Sahran, and Shukor (2012) advanced ERP hierarchy provides a superior explanation of ERP, with the general idea being that it should be viewed from five various viewpoints. More specifically, it should be considered as an easy data management system/large storehouse of organizational information, a set of modules connected to a single major database, a manufacturing philosophy rather than a software program, communication of business philosophy instrument, and lastly, a knowledge management system. These viewpoints have to be understood for the successful implementation of ERP, and as the firm obtains a higher value level, the different ERP system levels begin to increase from the least advanced viewpoint to the top complicated and tactical viewpoints. A firm that uses 
an ERP system should focus on the achievement of the top tactical points of view in the hierarchy of viewpoints.

On the other hand, BI refers to the effectiveness of a business in clarifying, planning, predicting, solving issues, and abstract thinking, comprehending, creating and learning to enhance information of the organization, provide information for decision making, and enable effective flexibility, as well as reinforce the achievement and establishment of the aims of the business (Hribar Rajterič, 2010). In other words, BI systems collect, transform, and reflect organized information on different levels (Ngai, Law, \& Wat, 2008). The systems hypothetical accounts for the scheduling of time to obtain data and enable effective usage and use concepts and methods to enhance business decisions with the help of facts and information obtained from supporting systems (Dresner, 2008).

Because the organizations not using such integrated system they lack reporting capabilities, majority of firms do their operations planning and management through spreadsheets (Helmy et al., 2012). Organizations should adopt ERPBI in order to be able to archive their objectives. It is therefore more feasible to use ERP in combination with BI, and not individually (Ince et al., 2013) as the combination of both has been evidenced to improve capabilities of corporate decision-making (Chen et al., 2012; Drelichowski, 2012; Yeoh \& Popovič, 2016).

A combined ERP-BI, known as ERPBI is capable of offering additional features, functionality and flexibility via information sharing (Fanning \& Centers, 2013; Helmy et al., 2012). The use of ERPBI enables management to understand processes and arrangement of data flows to facilitate access to significant amount of real-time operational data and to generate authentic reports for improving the process of decision-making (Hou, 2014; O'Mahony \& Doran, 2009; Ziemba, 2013).

The value of the ERPBI in a company is displayed by the models that facilitate information that underpins the platform upon which the fundamental changes can be conducted in an enterprise (new integration establishment, attraction of potential clients, expansion to new markets and new markets supply) (Celina M Olszak \& Ziemba, 2012).

\section{Past Researches on Enterprise Resource Planning and Business Intelligence (ERPBI)}

One of the top used ways to mitigate the failure rate of ERP and BI systems is to identify and examine the cases where its implementation succeeded, and this approach could lead to pinpointing various issues that crop up during the adoption of ERP. For example, by 
concentrating on the industrial ERP aspects, leaving out its environmental aspects and other aspects could lead to failed use and adoption. This may also be attributed to the increased academic and practical works and evidence in the literature of ERP. Several studies have been carried out to examine successful ERP implementation and these include (Wamba, Kamdjoug, Akter, \& Carillo, 2018) study, in the context of the Western world. However, in case of developing nations, issues are often related to lack of academic and practical works on the phenomenon. Therefore, future studies have to focus on carrying out further ERPBI studies in developing nations to develop an effective and appropriate model that facilitates adoption success.

To reiterate the need for studies, developing countries (e.g., India, Arab countries and Brazil) still need studies to be dedicated to the adoption of ERPBI to facilitate comparisons of results and to minimize the literature gap. ERPBI in developing nations are expected to have a high failure of adoption as they are lagging behind their developing counterparts in terms of their economic and industrial development.

In general, lack of studies has been noted by (M. Ali, Brooks, Alshawi, \& Papazafeiropoulou, 2006; Seethamraju, 2015; Wamba et al., 2018) throughout developing nations with different cultures. Specifically, in the Malaysian context, (Mirbagheri \& Khajavi, 2013) examined ERP among SMEs, focusing on the way the establishments leverage their adoption of the system through the evaluation of tangible and intangible categories. Based on their findings, superior resource management was the top intangible category followed by improved decision making and planning, with strategic gain supporting the business growth. The findings also highlighted hindrances for the adoption of ERP in Malaysia, and they include weak basis and lack of information, volatile political situation, lack of training and lack of support from the government.

In the Thailand context, (Sanzogni, Whungsuriya, \& Gray, 2008) examined ERP adoption among organizations and touched upon the issues faced. The authors proposed an adoption framework for Thailand and from the findings, it is clear that infrastructure, time and cost are the main barriers to ERP adoption success. They also stressed on the role of academia in developing nations, specifically Thailand in producing unskilled project members and providing insufficient training for critical training and skills for problem solving (Mexas, Quelhas, \& Costa, 2012).

In the Saudi case, scholars mentioned that the development of models and the identification of factors will play a role in the promotion of ERPBI and they contended that the 
lack of such models and information on factors are the main barriers of the adoption and usage of ERPBI.

The main objective behind the Saudi Vision 2030 is to promote economic growth via empowering and promoting entrepreneurial activities among the Saudi citizens (KSA Government Report, 2017). Entrepreneurs, specifically those having online businesses need guidelines on how to adopt ERPBI and the findings of the present work are expected to contribute to achieving Vision 2030 of Saudi Arabia for online entrepreneurs as it recommends the adoption of the system to help satisfying financial objectives and eventually, developing a strong economy.

The Saudi economy has been boosted through the use of enterprise recourse planning that has brought about the cognitive process, rules and procedures transformation among organizations. Along with such dynamic growth, particularly in the software industry, ERP packages are predicted to be used extensively in the near future (Al-Mobaideen, 2014). Most firms contended that their growth, welfare and dynamic progress owe themselves to the ERP system adoption - a specific system in light of scope and usage. In the present times, ERP vendors facilitate system adoption among SMEs.

In the contemporary organizations, focus has been shifted towards customers in a customer-centered and responsive environment by leveraging information systems like ERPBI and reaping the advantages they offer. Among the Arab countries, Saudi Arabia occupies top position in terms of networked readiness index in 2017 at the World Economic Forum - a forum that gauges the economies ICT performance (Saudi Government Report, 2017. Most SMEs in the Kingdom has begun ERPBI adoption despite the change resistance displayed by employees (Alhirz \& Sajeev, 2015; Badewi, Shehab, Zeng, \& Mohamad, 2017).

Furthermore, Saudi firms have been consistently exposed to increasing competitiveness that has urged them to adopt modern business processes like ERPBI solutions to provide access to unlimited information and enable them to obtain and maintain competitive edge (AlBar \& Hoque, 2017). The determinants of ERP growth in Saudi Arabian market environment covers higher return on investment (ROI), dynamic industrialization and integration ease into the legal systems.

Despite the large level of adoption of ERPBI systems, achieving and leveraging the benefits are still difficult primarily owing to the lack of integration and support from knowledge management and business intelligence (Al-Fawaeer \& Al-Zu'bi, 2013; Chan et al., 2011). More specifically, (Chan et al., 2011) developed an ERP integration framework using technological 
systems (ERP features and IT expertise) combination with ERP sub-systems, BI to support ERP sub-systems, KM support and contextual factors that can positively contribute to leveraging the predicted benefits from such systems.

Also, the integrated ERPBI system has been described as a robust system that is capable of addressing corporate resource planning and processing supply chain, and greatly contributes to the integration and management of enterprise extensive transactional data. Most systems of this type are capable of performing successfully but lack the necessary reporting and analytics data. In sum, if such gap is not minimized in decision-making, the BI tools can be used to maintain a consistent information technology innovation (D. C. Chou, Bindu Tripuramallu, \& Chou, 2005; P. Chou, 2018; Velić, Padavić, \& Lovrić, 2012).

Recent years have witnessed that the need to cut costs like on top of the significant business drivers list following ERP strategies (Ram et al., 2014). Along with the development and client advantage, contenders, development and client benefit are three factors that commanded the compressions that drive ERP use procedures but this does not mean that various points of views are unimportant. It is evident that ERP provides the value-based view that audits the record arrangement in some firms, and assists in meeting administrative and reporting needs. Nevertheless, these are given pre-requisites and ERP is generally considered as a crucial infrastructure and factors for BI as in the current studies have dominated (e.g., Adamala and Cidrin (2011); (Celina M Olszak \& Ziemba, 2012). Yeoh and Koronios (2010) revealed the comprehensive categorization of factors into four namely, authoritative, procedure, specialized and natural measurements/viewpoints.

Moreover, a combination of commercial and practical knowledge for achieving actual and agile ERPBI integration and its communal to search for data support but the business information requirements cannot be obtained at mandated levels or those that are attained are of bad quality that is unfeasible to use (Fanning \& Centers, 2013). Such subjects determinations calls for significant variables to business processes and as a consequence, Hou (2014) indicated that ERP users search for BI and Analytics to enhance their strategies and to achieve operations and enhanced performance of business.

More specifically, Hou (2014) examined the effect of ERPBI systems on the performance of organizations and suggested that is use in organizations provide performance gains. In Hawking and Sellitto (2010b) research, they adopted a content analysis method to validate a proposed model identifying the critical success factors related with the implementations of BI systems in an ERP environment. They identified several factors in the 
theoretical model according to prior literature but success was not measured for the model, to which the authors suggested further examination to identify all the critical success factors.

In addition to the above studies, Lee, Lee, Olson, and Hwan Chung (2010) conducted an examination of the effect of organizational support on behavioral intention towards ERP implementation in light of the technology acceptance model (TAM) and revealed a positive relationship between such support and TAM factors. The authors recommended that future studies develop and propose an integrated model that encapsulates actual use of the ERP and BI systems. Meanwhile, D. C. Chou et al. (2005) studied the profitability in terms of ERP and BI, while Fanning and Centers (2013) found attentiveness towards effective coordinated systems execution and use is crucial. The concerns found included mechanical advancement, sustained quality and accessibility, effectiveness of scale and adaptability of the framework. The ERP and BI were evidenced to improve IT execution and selection capacity in the association. In relation to this, speaking essentially of IT execution is important rather than focusing solely on general hierarchical execution as suggested by (Annamalai \& Ramayah, 2013).

Also, Hou (2014) looked into the impact of incorporating status asset arranging frameworks with business insight frameworks upon the execution of choice making - but the authors focused only on one industry. This study is the main article that focused on the status of developing nations.

Most studies dedicated to the topic were conducted in developed nations and they used various types of respondents, target population, cultural settings and choices of variables (Annamalai \& Ramayah, 2013). Only few studies focused on the factors that influence the practice of ERPBI and its incorporation in one model that could enhance the performance of the organization, indicating that a gap is present in literature. In the context of developing nations, it is notable that there are only a few authors that dedicated their work to ERPBI in business firms Chan et al. (2011); (P. Chou, 2018; El Amrani, Sarkar, \& Truex, 2010).

For instance, the study by Hawari and Heeks (2010) looked into the failed ERP project in a manufacturing firm, by assessing pre and post implementation of ERP through conferences, observations and document analysis. The findings showed that an extensive gap lies between the assumptions and the needs of building ERP system and the real time circumstances in the manufacturing organization.

In Malaysia, the successful ERP implementation was researched as a part of Mirbagheri and Khajavi (2013) examination of ERP among SMEs in developing countries. They delved 
into the way SMEs benefit from ERP implementation by evaluating two categories; tangible and intangible. They found superior resource management to rank the highest in the intangible category followed by enhanced decision making and planning, and strategic gain was found to support the growth of business. Several hindrances were highlighted for the ERP implementation in the context of developing nations, with some mentioned by previous researches to include weak basis and lack of information, unstable political situation, insufficient training and lack of government support.

In the same caliber of study, the ERP implementation in developing countries, particularly Thailand was examined by Sanzogni et al. (2008) by providing a discussion of the problems faced by the association in terms of network implementation. The study brought forward an implementation framework for Thailand and the findings showed infrastructure, time and cost as the factors that prevented the successful ERP implementation. The research laid emphasis on the key role of the academia in developing countries, particularly Thailand, in generating unskilled project members and the insufficient training for critical training and problem solving skills among staff of ERP (Mexas et al., 2012).

Moving on to enterprise recourse planning and business intelligence (ERPBI), it should be noted that it is not a simple piece of computer software owing to its ability to transform business process in the Kingdom of Saudi Arabia on the basis of different modules. Increasing number of organizations and industries are adopting the system and majority of Saudi organizations have displayed enhanced performance by using ERP and BI in light of their human resource planning, management control and operational control. Currently, researchers are of the consensus with regards to the potential promise that ERP holds in the manufacturing industries, with the combination of both systems (ERPBI) successful in bringing about core competency in majority of firms (Chan et al., 2011; Yusof et al., 2013).

More importantly, the economy of Saudi Arabia has been developing with the help of enterprise recourse planning that has facilitated the transformation of cognitive process, rules and procedures in organizations. With the dynamic growth of the Middle East software industry, ERP packages are expected to be extensively used in the long-run (Al-Mobaideen, 2014; Chan et al., 2011). Majority of companies claimed that their growth, welfare and dynamism are because of their implementation of ERP system - a system that is distinct for its scope and use. Presently, ERP vendors are generally catering to SMEs for system implementation.

Today's organizations are largely shifting their focus to customers by becoming 
customer centric and responsive in order to reap the benefits of information systems such as, BI and ERP. KSA, of the Arab countries, is positioned on top at the World Economic Forum's Networked Readiness Index of 2017 that measures the ICT performance in economies (Saudi Government Report, 2017). Majority of Saudi SMEs began adopting ERPBI although use resistance is still prevalent. It is pertinent for the ERP software to tackle and meet the enterprise needs of the firm in the social context, within the operation of the firm and these include local accounting practices, income tax, customs and sales tax.

Moreover, many Saudi firms exposure to increasing competitive pressure has led them to adopt modern business processes in the likes of ERP solutions in order to provide them with unlimited information access and allow them to obtain competitive advantage (AlBar \& Hoque, 2017). Factors that affect ERP growth in the Saudi market include higher return on investment (ROI), rapid industrialization and easy integration with the legal systems.

Regardless of the large scale ERPBI systems adoption, the achievement and leverage of the expected advantages are still complicated in the face of integration deficiency and lack of support from KM and BI (Al-Fawaeer \& Al-Zu'bi, 2013; Chan et al., 2011). In (Chan et al., 2011) study, the authors created an ERP integration framework on the basis of technological systems (ERP attributes and IT expertise) integration of ERP sub-systems, BI support of ERP Sub-systems, support from KM, and contextual factors that have a potential positive effect on reaping the expected advantages of ERP systems.

The integrated ERPBI system has been considered as a robust system used to handle corporate resource planning and processing of supply chain. ERP system significantly contributes to integrating and managing enterprise extensive transactional data. Majority of such systems are able to perform the feature successfully but they are lacking data reporting and analytics capabilities. To minimize, if not close, such gap, in decision making, BI tools can be utilized to keep the information technology innovation path consistent (Al-Adwan, 2020; Almeida, Barros, \& Maravilhas-Lopes, 2020; Ammar \& Mardini, 2020; D. C. Chou et al., 2005; P. Chou, 2018; Velić et al., 2012).

Lastly, as users are all organizational levels realize the advantages to be reaped from the BI software, its acceptance will increase. In this regard, firms that fail to justify ROI for the implementation of ERP are currently implementing BI software to enhance the former's usage. If users at all the levels of the organization are convinced of the benefits that can be obtained from the ERPBI software, they will increase their acceptance of it. In relation to this, firms failing to explain ROI for ERPBI adoption call for ERPBI adoption to improve the former. 
Since there is lack of the studies on the adoption of ERPBI model which can be used as guidelines for the successful adoption, the Saudi private sector is in need of a model to guide the ERPBI adoption success (Samander, Siam, Basri, \& Hamed, 2017).

\section{Extracting the Factors that Affect Behavioral Intention to Use}

Majority of methods have been evidenced in literature to be determinants of ERPBI adoption, with the most common among them tabulated in Table 1. Every approach included in the table has its strengths and weaknesses elaborated to add to their clarification (Khandewal \& Miller, 1992). The different techniques were clarified by Khandelwal and Ferguson (1999).

Table 1 - Literature Approaches

\begin{tabular}{l|l}
\multicolumn{1}{c|}{ Research method } & \multicolumn{1}{c}{ Authors } \\
\hline Action-research & (Kock, Jenkins, \& Wellington, 1999) \\
\hline Case studies & (Holland, Light, \& Gibson, 1999) \\
\hline Structured interviewing & (Bullen \& Rockart, 1981) \\
\hline Scenario analysis & (Barat, 1992) \\
\hline Multivariate analysis & (Tishler, Dvir, Shenhar, \& Lipovetsky, 1996) \\
\hline Literature review & (Esteves \& Pastor, 2001) \\
\hline Group interviewing & (Khandewal \& Miller, 1992) \\
\hline Focus groups & (MacCarthy \& Atthirawong, 2001) \\
\hline Delphi technique & (Brancheau \& Wetherbe, 1987; Lawley, \\
& Summers, Koronios, \& Gardiner, 2001) \\
\hline Combination of methods & (Khandelwal \& Ferguson, 1999; Parr \& Shanks, \\
& 2000) \\
\hline
\end{tabular}

Source: Aldossari and Mukhtar (2018).

The present paper reviewed ERPBI literature to identify the factors used by the authors, and it highlighted 71 factors that are of importance (refer to Table 2). On the basis of the frequency table, 28 factors of ERPBI are pertinent for its usage and adoption. 
Table 2 - Factors Extracted from Literature Review

\begin{tabular}{|c|c|c|}
\hline Group of Factors & Factors & Total \\
\hline Individual & $\begin{array}{l}\text { Training, Attitude about Use, Individual Characteristics, } \\
\text { Subjective Norm, Self-Efficacy, Satisfaction, Motivation, } \\
\text { Personal Beliefs, Education, Age, Experience }\end{array}$ & 11 \\
\hline Technological & $\begin{array}{l}\text { Effort Expectancy, Personal Normative, Belief, Self-Identity, } \\
\text { Perceived Consequences, System Quality, Perceived Ease of } \\
\text { Use, Perceived Usefulness, Features Used, Trust, } \\
\text { Compatibility, Privacy, Information Technology Challenges, } \\
\text { Service Quality, Technological Readiness, Privacy, Efficiency, } \\
\text { Reliability, IT infrastructure, Interactivity, Information } \\
\text { Quality, Reliability, Responsiveness, Efficiency, } \\
\text { Effort expectancy }\end{array}$ & 25 \\
\hline Organizational & $\begin{array}{l}\text { Human resources , Motivation, Resources Available, } \\
\text { Perceived Financial Cost, Information need, Competition, Top } \\
\text { management Support, Standardization, Change Management, } \\
\text { Outsourcing, Social Influence, Facilitating Conditions, Training } \\
\text {, Effective Communication }\end{array}$ & 14 \\
\hline Environmental & $\begin{array}{l}\text { Clear Vision and Planning, Laws and Legislations, Policy } \\
\text { Government Role, Competitiveness Pressure, Security } \\
\text { Concerns }\end{array}$ & 5 \\
\hline Behavioral & $\begin{array}{l}\text { Usage Intentions, Habit, Intention to Use, Enjoyment, User } \\
\text { Expectations, Extrinsic Motivation, Intention, User } \\
\text { Involvement, Relationship with Developers, Overall } \\
\text { Satisfaction }\end{array}$ & 10 \\
\hline Net Benefit & $\begin{array}{l}\text { Improved Efficiency, User Satisfaction, Performance, Output } \\
\text { quality, Organizational Competence, Perceived Benefits }\end{array}$ & 6 \\
\hline
\end{tabular}

Source: Aldossari and Mukhtar (2018).

Frequency reflects the number of citations of the factors in literature but it does not make the factors common and ordinary as explained by (Finney \& Corbett, 2007; Law \& Ngai, 2007) and shown in table 3.

The obtained factors were forwarded to experts for perusal and ranking in order to choose the ones that have significant effect on the integrated ERPBI system. 
Table 3 - The Most Cited and Frequent Factors Extracted through Intensive Literature Review

\begin{tabular}{|c|c|c|c|c|c|}
\hline No & Factor & Frequency & No & Factor & Frequency \\
\hline 1 & $\begin{array}{l}\text { Top management } \\
\text { support }\end{array}$ & 33 & 15 & Software development & 23 \\
\hline 2 & User involvement & 25 & 16 & Partnership & 23 \\
\hline 3 & Perceived usefulness & 30 & 17 & External Expertise & 23 \\
\hline 4 & Information Quality & 28 & 18 & System Quality & 20 \\
\hline 5 & Effective communication & 28 & 19 & Policy & 19 \\
\hline 6 & $\begin{array}{l}\text { Clear vision and } \\
\text { planning }\end{array}$ & 27 & 20 & Service Quality & 17 \\
\hline 7 & $\begin{array}{l}\text { Team work and } \\
\text { composition }\end{array}$ & 27 & 21 & $\begin{array}{l}\text { Consultant selection and } \\
\text { relationship }\end{array}$ & 17 \\
\hline 8 & Legacy system & 25 & 22 & Financial Support & 17 \\
\hline 9 & Change management & 25 & 23 & Competitive Pressure & 16 \\
\hline 10 & Vendor support & 25 & 24 & Usability & 15 \\
\hline 11 & Government Role & 24 & 25 & Training & 14 \\
\hline 12 & $\begin{array}{l}\text { Data quality and } \\
\text { integrity }\end{array}$ & 24 & 26 & Overall Satisfaction & 13 \\
\hline 13 & $\begin{array}{l}\text { Effective monitoring and } \\
\text { control }\end{array}$ & 24 & 27 & Performance & 12 \\
\hline 14 & Risk management & 24 & 28 & Reliability & 12 \\
\hline
\end{tabular}

Source: Aldossari and Mukhtar (2018).

The remaining factors only had few citations and were therefore dropped from the list. Figure 1 depicts the factors ranks on the basis of the citations frequency.

Figure 1 - Ranking of Factors

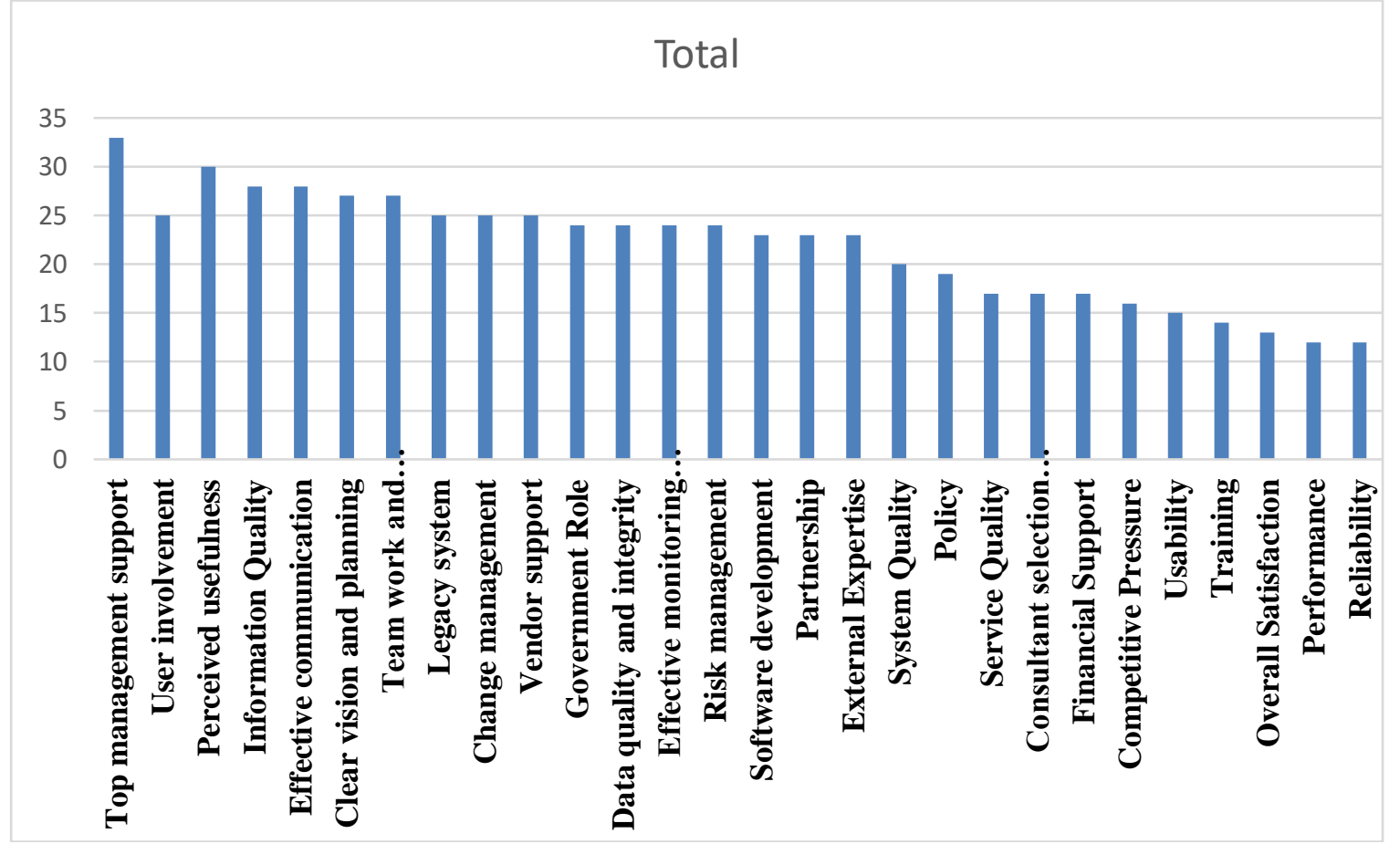

Source: Aldossari and Mukhtar (2018). 
As mentioned, experts perused the list of factors and their feedback were obtained in terms of factors that influence ERPBI system integration, after which, nine factors were considered to be important to the behavioral intention towards ERPBI adoption, and consequently, actual use. (Hawking \& Sellitto, 2010a) and (M. M. Ahmad \& Cuenca, 2013) recommended determining such significant factors (Refer to Table 4).

Table 4 - List of factors recommended by experts

\begin{tabular}{llc}
\hline No & \multicolumn{1}{c}{ Factor } & Number of recommenders experts \\
\hline 1 & System Quality & 30 \\
2 & Government Role & 30 \\
3 & Competitive Pressure & 30 \\
4 & Change management & 28 \\
5 & Effective communication & 28 \\
6 & Clear vision and planning & 27 \\
7 & Information Quality & 27 \\
8 & Service Quality & 25 \\
9 & Training & 25 \\
10 & Behavioral Intention & 25 \\
11 & Performance & 24 \\
\hline
\end{tabular}

Source: Aldossari and Mukhtar (2018).

The initial methodology phase identified the variables extraction in order to assess behavioral intention to use ERPBI among the Saudi SMEs. Following the factors extraction, the final list was forwarded to experts for perusal. This approach has been recommended by (Mukred, Yusof, Mokhtar, \& Fauzi, 2018).

\section{Methodology}

This section is allocated for the methodology that has been followed in this paper. It starts with the research design followed by research approach. The last subsection is dedicated for the data collection strategy that had been used in the paper.

\section{Research Design}

A four-phase method was adopted in this study to meet the study objectives. The four phases include the following (refer to Figure 2), conducting an intensive literature review, extraction of factors, interviewing the experts concerning the ERPBI factors, and conducting a thematic analysis to examine the resulting study factors. 
Figure 2 - Research Design (Mukred et al., 2016)

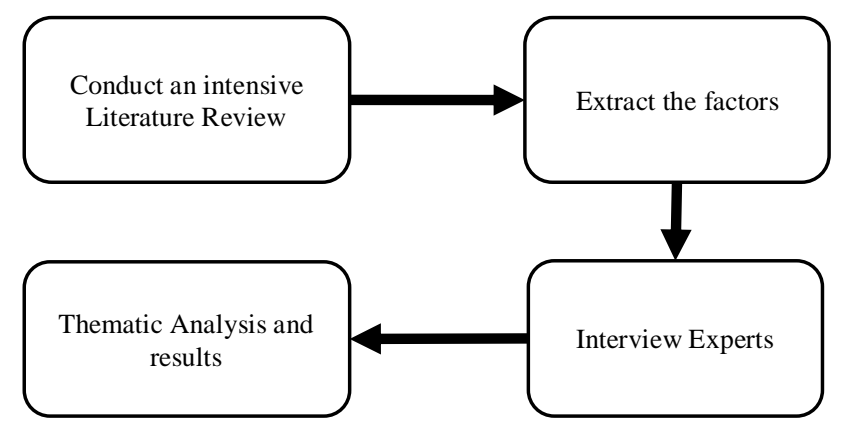

Source: Aldossari and Mukhtar (2018).

\section{Research Approach}

The present study adopted a systematic and logical set of phases. The selection between adopting a quantitative, qualitative or a mixed approach largely hinges on the objectives of the research as explained by (Creswell, 2013) . Specifically, quantitative research approach is often utilized to explore the relationship between variables in light of objective theories, while qualitative research approach is often used when the objectives of the research are related with individuals, individual groups, social or human issues. Majority of information system studies, have selected either qualitative or quantitative but the combined approach is becoming more often owing to its ability to obtain significant information (Komba \& Ngulube, 2015).

There are three major types of mixed-method research namely, explanatory, exploratory and triangulation methods (Creswell, 2013). The first one is one where quantitative study is conducted followed by a qualitative study. The second one employs a quantitative study depending on the outcome of the earlier qualitative study, whereas the third is considered to be the top common approach. It interprets data from qualitative and quantitative methods, with the goa(Harris \& Brown, 2010)l being to confirm the study results with the use of both methods.

Structured questionnaires and semi-structured interviews generated confirmatory outcomes in researches of mixed-methods. This was supported by (Komba \& Ngulube, 2015) who explained that mixed method enables researchers to provide an extensive overview of the phenomenon under study and the realization of the research objectives. Mixed methods provide a clear and valuable insight using data, enabling for the development of accurate theories. According to (Myers, 1997), in the social science field, qualitative research methods enable the examination of social and cultural phenomena and that such methods provide further understanding of individuals and their environment's social and cultural aspects. Qualitative 
studies are crucial owing to the insight they bring into the perceptions and behaviors of individuals via observations and questions.

In addition, this study conducted semi-structured interview sessions with 30 participants working in the private sector, with each interview lasting between 10-20 minutes, an average of 15 minutes each. The interviews were recorded, except those who wanted their interviews to be classified and confidential.

The details of the experts who have involved in this study are shown in Table 5.

Table 5 - Experts Profiles

\begin{tabular}{|c|c|c|c|}
\hline Position & Specialist Areas & Experience in SME & $\begin{array}{l}\text { Number of } \\
\text { respondents }\end{array}$ \\
\hline Applications & Solution & Billing systems & 9 \\
\hline Integration Manager & $\begin{array}{l}\text { Integration and } \\
\text { Testing }\end{array}$ & Transactions & \\
\hline $\begin{array}{l}\text { Planning and } \\
\text { Coordination } \\
\text { Department Manager }\end{array}$ & $\begin{array}{l}\text { Oracle Products } \\
\text { SAP products }\end{array}$ & $\begin{array}{l}\text { Oracle development and } \\
\text { design tools } \\
\text { Oracle database } \\
\text { administration } \\
\text { Project management and } \\
\text { implementation } \\
\text { SAP Developer }\end{array}$ & 6 \\
\hline Business Analyst & $\begin{array}{l}\text { Business } \\
\text { Process }\end{array}$ & $\begin{array}{l}\text { Solutions business process } \\
\text { mapping } \\
\text { Project implementation }\end{array}$ & 10 \\
\hline Top Management & $\begin{array}{l}\text { Financial Manager } \\
\text { Human Resource }\end{array}$ & $\begin{array}{l}\text { Customer relationship } \\
\text { management systems } \\
\text { Auditing }\end{array}$ & 5 \\
\hline
\end{tabular}

Source: Aldossari and Mukhtar (2018).

Table 5 shows the profiles of the experts involved in the ranking of the study factors. As listed in the table, nine experts work as application integration managers and have experience in billing systems and transactions. Those experts were specialists in solution integration and testing. On the other hand, there are six experts from the planning and coordination department who worked as managers and specialists in Oracle and SAP products. They are also experts in Oracle development and design tools, Oracle database administration, Project management, and implementation and SAP Developers as well. Moreover, ten experts work as business analysts and have experience in the business process especially in solutions business process mapping and project implementations. Besides, five experts from the top 
management have experience in financial management and human resource. Those experts are specialists in customer relationship management and system auditing.

Moreover, the VOIP applications were adopted for the interviews, with each beginning with an introduction to the interviewer and the study purpose. The interviewees' confidentiality and privacy were guaranteed while focusing on the issues facilitating or barring behavioral intentions to use ERPBI and the private sector strategies adopted for ERPBI adoption success. Such methodology was adopted from Mukred et al. (2016) (refer to Figure 2).

The collection and analysis of qualitative data furnish information on the phenomenon under study. Therefore, this study employed qualitative data for the optimum understanding of the factors that have a key role in the adoption of ERPBI. According to Myers (1997), the top commonly utilized qualitative data collection methods are interviews, documentation, and observations. Interviews are generally utilized for data collection after which data obtained is combined with that obtained from the quantitative data collection methods to support the outcome. The interview method was adopted in the study to gather qualitative data from the participants.

Specifically, Brenner, Green, and Camilli (2006) explained that the interview method is employed for data collection of experiences and perceptions of participants. In this interview process, the participants are asked open-ended questions about the target topic and the answers provided reflect the personal experiences of the interviewees and they are recorded (Creswell, 2013). The interview outcomes shed light on the phenomenon much more than the static data gathered from quantitative methods. Furthermore, interviews ensure that quantitative results are consistent, in a mixed method study.

\section{Data Collection Strategy}

The main focus of this study was SMEs in Saudi. Saudi SMEs are contributor to the growth of the country's economy which in return have the potential to take roughly on employment and profitability.

This study employed an interview approach. A total of 30 specialists were targeted to answer the paper based interview. The mentioned specialists are from the Saudi SMEs who are familiar with the ERPBI and IS. Interview sessions are conducted to obtain the administrators and employees' opinions on the factors that influence the ERPBI adoption. An interview is appropriate to be utilized in achieving the present study's objectives. 
According to Creswell (2013), interviews can be conducted face-to-face, telephone, email, or in a focus group. Creswell argued that although face-to-face interviews are timeconsuming and expensive, they are widely used in research. In this paper, individual face-toface interviews were a suitable method to obtain the required data from the targeted SMEs. The open-ended questions were directed to the participants to get the corresponded data required to answer the questions. It meant to give participants a chance to provide detailed information. Finding answers to questions requires the type of semi-structured interview interaction with participants that is best obtained by interviews.

While validation in quantitative data methods is based on statistical standards; the validity of interview data relies on the procedures for gathering data and the design of the collection instrument (Brenner et al., 2006). Several procedures can be used to validate qualitative data, such as triangulation, member checking or peer debriefing (Brenner et al., 2006; Creswell, 2013). Many reviewers consider participant validation of qualitative research to be a mark of quality, and evidence of participant validation. The validation process in this study was achieved through member checking. Firstly, the researcher checked transcripts to ensure that they are free from mistakes. Secondly, each participant gets a copy of the Arabic interview transcript and recorded copy. According to (Creswell, 2013), the review of the transcription and translation suited the data member validation. Thirdly, the English language expert translated the transcription of the interview from Arabic to the English language.

Deciding on whether the data will be hand or computer analysed is based on the amount of data, if the data are less than 500 pages, then the data can be analysed by hand (Creswell, 2013). Thus, since the qualitative data size in this study is small, it was analysed manually through thematic analysis.

In this regard, and according to Lacey and Luff (2001), the mass of words generated by interviews in qualitative data analysis needs to be described and summarized. They added that the thematic analysis can be applied to the data by using numerical or textual codes to identify specific parts of the data that correspond to differing themes. Creswell (2013) added that the qualitative data analysis may be both a description of the story and themes that emerge from it.

\section{Proposed Model for ERPBI}

Any research needs to understand the relevant theory as it directs the researcher in generating a logical opinion of the relationship between constructs in model development. In 
this study, the TOE framework was adopted and extended to base the classification of factors on. The study aims to develop an ERPBI adoption underpinned by UTAUT.

More importantly, the UTAUT was created based on eight well-known competing technology acceptance models in light of their conceptual and empirical similarities. The eight models are Social Cognitive Theory by (Bandura, 1986), the Theory of Reasoned Action (TRA) by Fishbein (1979), the Technology Acceptance Model (TAM) by Davis, Bagozzi, and Warshaw (1989), the Theory of Planned Behavior (TPB) by Ajzen (1991), the Motivation Model (MM) by (Davis, Bagozzi, \& Warshaw, 1992), the Combined TAM and TPB by Taylor and Todd (1995), the Innovation Diffusion Theory (IDT) by Rogers Everett (1995) and the Model of PC Utilization (MPCU) by (Thompson, Higgins, \& Howell, 1991).

In the present study, the employees' behavioral intention to adopt ERPBI is examined by using UTAUT model. Despite the capability of the UTAUT to explain behavioral intention towards technology adoption and use, the initial UTAUT's main concentration was on largesized organizations. Authors have evidenced the model's validity and reliability in explaining acceptance, adoption, and use of technology and deemed it suitable for large organizations (Venkatesh, Morris, Davis, \& Davis, 2003). Additionally, the UTAUT model combined as many of the factor categories as possible that influenced user adoption of IT (technological, organizational and environmental) (Venkatesh et al., 2003). Studies dedicated to an examination of ERPBI are still few and far between and no other model other than the UTAUT is more suitable to examine ERPBI adoption owing to its extensive application to other IT contexts.

The factors need to be clear, visible and understandable throughout the process of adoption and hence, they are referred to as predominant and are displayed in Figure 3 which depicts the study model that is used to align the relationship of varying parameters and factors based on the TOE dimensions. In particular, the technological dimension has its based on the DeLone and McLean's IS Success model factors namely system quality, service quality and information quality, while the organizational dimension covers change management, effective communication and training (obtained from literature and experts). Lastly, the environmental dimension includes clear vision and planning, competitive pressure and government role (obtained from literature and experts). The organizational and environmental dimensions were obtained from UTAUT, as the underpinning model. 
Figure 3 - Proposed Model for ERPBI Adoption in the Private Saudi sector

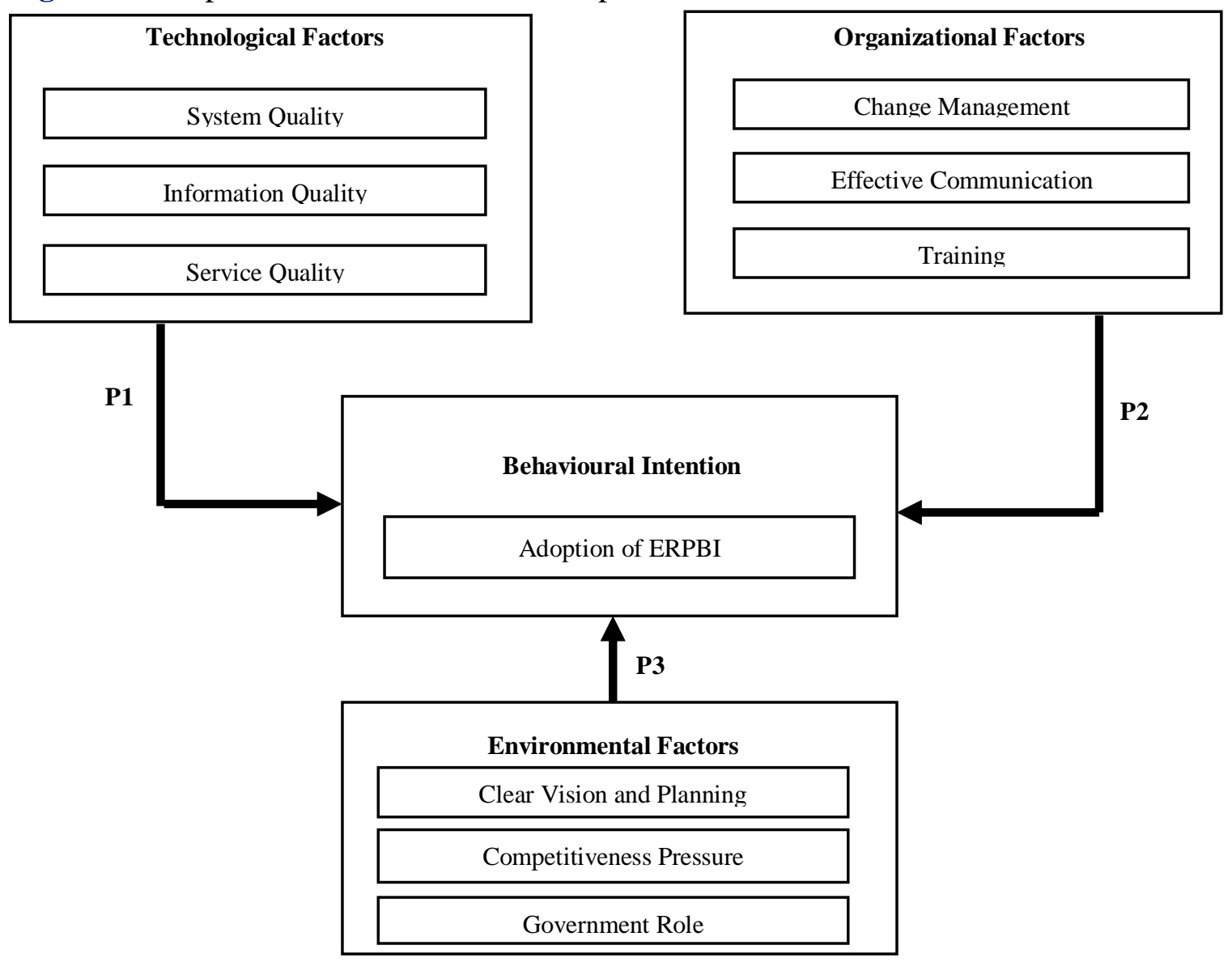

Source: Aldossari and Mukhtar (2018).

The model above combines the entire factors crucial for ERPBI adoption success among SMEs. Prior literature addressed some factors (technological/organizational/technological) but the model encapsulates the top critical ones and is expected to contribute to the ERPBI system field in the context of Saudi SMEs.

Literature reveals the Saudi SMEs inability to adopt ERPBI system. Among the major objectives of this study is to tackle the issues that surrounded the adoption of ERPBI model and the development of such model. The model developed by the present study came about through the analysis of technical factors influence on the system adoption among staff. This study used Delone and McLean (2003) model to conduct an evaluation of the intention to adopt ERPBI among staff. Majority of studies in literature viewed the adoption of ERPBI, using UTAUT, with or without changes. On the basis of the success of the prior studies, the present one made use of UTAUT to determine the ERPBI level of adoption. The study used an integrated version of UTAUT and De Lone and Mc Lean's (2003). The propositions tested are as follows;

Proposition 1 (P1): Technological factors positively influence intention to adopt ERPBI. 
Proposition 2 (P2): Organizational factors positively influence intention to adopt ERPBI.

Proposition 3 (P3): Environmental factors positively influence intention to adopt ERPBI.

\section{Results and Discussion}

Under this sub-section, the study discusses the findings acquired from the qualitative analysis gathered from the interviews with Saudi SMEs specialists. The data obtained via interview was analyzed through thematic analysis.

The sequence of steps followed in the thematic analysis of interviews (Braun \& Clarke, 2006) is as follows; in the first step, each recorded interview was transcribed and translated from Arabic to English after which the transcripts were repetitively read to make sure that the statements are linked together. The analyzed transcripts were used as a basis for the final analysis and write-up of the findings obtained from the qualitative analysis. Data was then examined based on keywords and linking phrases, forming codes. Substantive themes were culled from the interviews, while ignoring the data replications. Lastly, the themes formed the structure of this section regarding the aim of the research - developing an ERPBI model for SMEs.

The interview questions were qualitatively analyzed, based on which the researcher decided to hand or computer analyze the data based on the amount obtained - data of less than 500 pages can be manually analyzed with each (Creswell, 2013), and that was how it was done in this study.

In this stage, the researcher familiarized himself with the data through transcription, reading and re-reading and noting down important ideas. The second step in this phase includes the creation of the themes based on prior studies and specific themes, referred to as theorydriven codes and data-driven codes respectively. The theory driven code involves coding data based on specific research questions (Braun \& Clarke, 2006). This is followed by data categorization into the developed themes and the generation of a thematic analysis map from the categorization. Each theme is defined and provided a label, and the next step entails the reporting of findings from the row data obtained samples and linking them to the research questions and literature findings. In the thematic analysis, different aspects of research topics are encapsulated on the basis of their link to the research questions. 
Therefore, the data taken from the interviews was analyzed using thematic analysis to determine answers to the research questions. Braun and Clarke (2006) explained that the thematic analysis entails a sequence of steps namely, data translation, data familiarization, producing initial codes, determination of themes, producing the report, defining and naming themes and reviewing themes. The researcher highlighted three primary themes that are deemed to be of top importance to provide the answers to the third research question. The following sections discusses the results with the past results according to the dimensions as follows;

\section{A. Technological Factors}

The experts were in a mutual agreement that technological factors such as system quality, service quality and information quality are vital for ERPBI adoption. This results are in line with other previous works as follow;

According to Delone and McLean (2003), an information system is gauged through the system output quality. Such quality is linked to the components of the software and data that assesses the health of the technical system aspects (Gorla, 2011), which has a significant influence on its effectiveness. Effectiveness of the system its ability to do what it is meant to do.

In a related study, Zheng, Zhao, and Stylianou (2013) examined the quality of system effect and they referred to quality as the system's ability to run processes without breaches and its readiness was tested through the engagement of processes. Moreover, in Annamalai and Ramayah (2013) study, a factorial and structural equation analysis was employed to measure successful enterprise system based on the features that influence ERP projects.

A thorough review of literature indicated several definitions provided for information quality. To begin with, Gorla (2011) indicated that information quality is linked to the perceived value in the user's view. The study further indicated that information is perceived as having high quality if it satisfies the user specifications, expectations and requirements. Meanwhile, (Pérez-Mira, 2010) categorized information into required information and obtained information, with the former meeting the aesthetic, cognitive, functional and technical requirements of the users. The quality of information will have the potential to significantly influence the IS effectiveness. The review of literature illustrates the significant influence of information quality on the system (e.g., (Komba \& Ngulube, 2015; Mukred \& Yusof, 2017)). Judging from the importance of information quality, it is worth considering during the selection and adoption of information system (Petter, DeLone, \& McLean, 2013). The information 
quality is linked to the accuracy and knowledge of the overall system and the generated new information. A good way to make sure that the system requirements for information quality can be met is to acquire the end users feedback (A. S. B. Ali \& Money, 2005; Mukred, Yusof, \& Alotaibi, 2019; Mukred, Yusof, Alotaibi, Asma'Mokhtar, \& Fauzi, 2019; Mukred, Yusof, Mokhtar, et al., 2018; Mukred, Yusof, Noor, Kayode, \& Al-Duais, 2019).

Service quality is another variable considered in the present study and it is described as the difference between normal service expectations and actual performance from the user's perspective. Service quality depends on the service types offered (Gorla, 2011). In another related study, Al-Hudhaif (2010) viewed service quality on the basis of service accuracy and reliability and based on other studies, reliability is one of the top characteristics of quality service. In the current digital environment, reliability enhances the organization's trustworthiness as it represents the entity's consistency and reliability (Hsiao, Li, Chen, \& Ko, 2009). The service quality of ERPBI hinges on its ability to satisfy the SMEs requirements, in that good quality service boosts the adoption and use of the system among users (Motaghian, Hassanzadeh, \& Moghadam, 2013). Studies in literature (e.g., (Althonayan \& Althonayan, 2017)) evidence the importance of technological factors for ERPBI in developing nations' context and this is true for the present study's findings.

\section{B. Organizational Factors}

According to the qualitative data findings, organizational factors are important. Those factors are, change management, effective communication and training.

The experts are in a mutual agreement that all the factors in the organizational dimension of the model are vital in successful adoption of ERPBI. This results is supported by previous related works which indicated that there this set of factors were affect ERPBI. Change management involves the ability to foresee future company changes, selection of platforms to address the changes and its effective management (Hayes, 2014). Change management refers to a strategy employed to properly manage change from the traditional models to new ones. In the ERP case, the organizations have to prepare their employees to tackle various changes. In fact, the organization holds the responsibility of formally providing change management initiative to tackle any complication that presents itself when the change is happening and these include employees' resistance, redundancies and ambiguities and errors that are brought about by the new model (Finney \& Corbett, 2007; Françoise, Bourgault, \& Pellerin, 2009; Muaadh, 2014; Mukred, Yusof, \& Alotaibi, 2019; Mukred, Yusof, Alotaibi, et al., 2019). 
Additionally, change management balances the forces and urges inclination towards embracing change rather than resisting it (Almajali et al., 2016; Masa'deh, Obeidat, \& Tarhini, 2016). On the other hand, lack of change management could lead to the failure of ERP adoption as evidenced by previous works (Al-Shamlan \& Al-Mudimigh, 2011); Altamony, Al-Salti, Gharaibeh, and Elyas (2016); (Hawking \& Sellitto, 2017). Thus, successful use of ERPBI has to be supported via change management (Altamony et al., 2016), which shows that change management may be a significant factor influencing behavioral intention towards ERPBI adoption in the context of Saudi private organizations.

More importantly, the ERPBI needs communication that is clear and effective at every company level as revealed by Nah, Zuckweiler, and Lee-Shang Lau (2003) and Altamony et al. (2016), communication is related with the development of a formal team that handles ERPBI projects and marketing. Experts assured that effective communication is a crucial success factor and it influences the acceptance of technology (e.g., ERPBI) and its implementation in the workplace.

Furthermore, Al-Mudimigh, Zairi, and Al-Mashari (2002) concluded that effective communication is important for ERP adoption and such adoption has to be communicated throughout the ERP project life cycle. It is pertinent for users to participant in relaying their feedback on the response, comments and approval in terms of the requirements (Mandal \& Gunasekaran, 2003).

Additionally, effective communication is important for the use and adoption of ERP (Mayeh, Ramayah, \& Mishra, 2016) because communication coupled with the required successful system control factors all play a significant role (Misra, Singh, Jha, \& Bisui, 2016). In fact, high and effective communication leads to high potential system use. Evidently, effective communication has to be established as one of the top ERP factors and thus, it is should be viewed as a crucial organizational dimension.

Another organizational dimension factor is training and it is one of the success factors of ERP use. In using ERP, knowledge is required to allow users to provide solutions to various issues in the model; for instance, in case the employees lack the requisite knowledge, they may create their own process use through model components modification. User's training determines $42.20 \%$ of the overall ERP use success and in turn, system adoption success. Users that are knowledgeable understand the new model concepts more and they will be more inclined to using it and not resist training provided for it (Altamony et al., 2016). 
As agreed by experts in the fining of this study and evidence by reviewed literature, successful ERPBI adoption needs the principals to have enough training through in-service programs, conferences, seminars and workshops in order to run system functionalities. Hence, training is considered in this study. Staff training makes sure that the risks that can prevent successful adoption of the system are overcome (Ludwick \& Doucette, 2009) - on the other hand, lack of technical training and support can hinder the adoption of the system among employees (Miranda, Farias, de Araújo Schwartz, \& de Almeida, 2016). Also, lack of training can also make it appear to the users that the system is unfamiliar to this will make them resist its adoption (Huryk, 2010).

Lastly, according to Chen et al. (2012), the main objective of the ERPBI system is to allow employees to learn how to use the system and as such, training programs have to be provided that are of high quality to enable employees' system use and to change the process operations for better usage. Successful ERPBI adoption therefore hinges on the satisfaction of users and training is one of the organizational dimensions examined in this study that assist in such adoption.

\section{Environmental Factors}

Notwithstanding the benefits offered by ERPBI adoption, researchers showed the unusual failure rate in such adoption owing to the manifold challenges that are brought about by the environmental factors (Mukred, Yusof, Asma'Mokhtar, \& Fauzi, 2018; Pan \& Jang, 2008). This sad fact is a reflection of the actual priority of the successful ERP system implementation in both research and practice (Bradford, Earp, \& Grabski, 2014; Nzuki \& Okelo-Odongo, 2015). Past literature also evidenced the lack of examination of the entire required factors for adoption and usage, and as such, the present study, includes clear vision and planning, competitive pressure and policy, and government role as factors of environmental dimension worth examining. The support of the environmental factors has been indicated to be a significant dimension in innovation adoption (e.g., ERP) (Al Bar, Mohamed, Akhtar, \& Abuhashish, 2011) and business intelligence (BI) (Nasab, Jaryani, Selamat, \& Masrom, 2017). Under the environmental dimension, the factors for ERPBI adoption are discussed below in detail;

First, setting plans and visions is mandatory towards the ERP and BI processes use as it plays a role in gaining accurate business strategy and plan before the beginning of the project. Also crucial is the creation of a clear business model and informative strategy that can be 
utilized in the phases of adoption (Nah et al., 2003; Ngai et al., 2008). Planning generally establishes the project overview with the related decisions for the team members to comply with.

In the case of businesses, it is important for entrepreneurs to extend their time period for the long-run and consider a realistic situation, carry out future envisioning and goals, critical needs, steps and strategies visualizations. Nevertheless, an extensive vision without effective expectations and planning can lead to nothing but failure (Picken, 2017). In addition, clear vision and planning factor has been evidenced to be related to the adoption of BI technology and satisfaction of users (Bargshady, Alipanah, Abdulrazzaq, \& Chukwunonso, 2014) and hence, this study considers it as one of the factors influencing behavioral intention towards ERPBI use in the context of Saudi SMEs.

Competitive pressure is also another factor under this dimension that has been evidenced by prior studies as affecting ERP adoption and performance (Ramakrishnan, Jones, \& Sidorova, 2012). Competitive pressure is described as the pressure level that the firm receives from its rivals. Using IT innovation can enable firms to compete in three ways, which are; to change the rules of competition, change the industry structure and utilize new ways for the creation of competitive edge to outperform rivals (Global, 2010). In regards to this, ERPBI system can help in making decisions, coordinating departments, facilitating operational efficiencies and mitigating stock turnover.

In a study of the same caliber, Chan et al. (2011) showed that dynamic competitive pressure boosts firms to adopt IT business processes including ERPBI solutions to have information access and effective competitive edge. In the Saudi case, some of the factors revealed to influence the market growth of ERP are higher return on investment (ROI), increasing industrialization and ease in integrating the legacy system transaction, time of processing and overall costs (operating and administrative), supporting business alliances and business growth, development of business innovations and generating differentiation in products (Shang \& Seddon, 2007). These advantages help firms to obtain and maintain competitive advantage in relation to their rivals.

Based on the above discussion it can be decided that the actual scenario is that the ERP system adoption would leave rivals behind the first mover and those who adopt ERP in a timely manner will be benefited by competitiveness and the motivation to outperform rivals. This is why competitive pressure plays an important role in system adoption. On the basis of empirical studies, competitive pressure is just a single factor that explains behavioral intention towards 
IS use (Negash \& Gray, 2008). Such pressure is frequently revealed as a top driver strategically, specifically in decisions concerning enterprise-extensive IS. In relation to this, increasing numbers of organizations are turning towards IT platforms, with the remaining rivals urged to react to it. This will eventually force organizations to adopt IT platforms to stop first movers from obtaining first mover advantages.

In effect, the present study creates a model that includes competitive pressure as one of the factors that drive ERPBI use in the context of private firms in Saudi Arabia. This factor was recommended by experts during the interview.

Moreover, studies dedicated to the Saudi Arabian context showed that government involvement and support in establishing regulations and effective infrastructure have a key role in the promotion of technology adoption (Mohammed, Ibrahim, Nilashi, \& Alzurqa, 2017) as ERPBI (Hartley \& Seymour, 2015; Kasemsap, 2017). Authors indicated that the lack of established laws and regulations concerning ERPBI and data security and privacy can prevent its successful adoption. This is worsened by the lack of trust in ERPBI system among the users that has been linked to the missing regulations that support it. In Saudi Arabia, citizens indicate a greater inclination to trust government initiatives and as such, government support is significant in the adoption and use of the system.

Saudi vision 2030 mainly addresses the economic growth promotion via empowering entrepreneurial activities among Saudi citizens (KSA Government Report, 2017). Entrepreneurs, specifically those online, have to be guided through established guidelines when it comes to ERPBI adoption. Hence, the obtained findings in this study are expected to contribute to Saudi Vision 2030 for internet entrepreneurs. The study recommends system adoption to facilitate the achievement of financial objectives and eventually, developing and maintaining a robust economy. The study model investigates the role of the government in motivating intention towards ERPBI use in the private firms in KSA.

As a whole, this study obtained factors that are significant for behavioral intention towards ERPBI use and adoption via the reviewed literature and experts' recommendation. The data obtained from the interviews were consistent with the extracted factors and the experts' recommendations provided in the list of the top ERPBI adoption factors. The experts also confirmed that ERPBI adoption enhances the overall Saudi private sector performance. The model factors are categorized into three main dimensions namely technological, organizational and environmental factors (refer to Figure 3). 


\section{Implication of the study}

The factors that determine ERPBI use, specifically in the developing nations, have to be confirmed and highlighted to ensure effective utilization of IT resources. In this regard, literature on the subject has been few and far between in this context, particularly in Saudi Arabia. It is therefore pertinent to have a deeper insight into the ERPBI principles in developing nations to benefit software suppliers and organizations. This would also assist decision makers in designing a suitable ERPBI set of strategies and software designers and suppliers in designing products/services that could meet the requirements of the end-users.

The understanding of the factors and their relationship with the successful use of ERPBI would assist top management to steer clear of or mitigate organizational losses while using the system for increased cash flow, controlled expenses, management of headcount and enhanced employee performance, streamlined spend-supply chain operations, tracking the financial performance of key projects, enhancing customer relationships and reporting systems that will ultimately result in overall organizational performance. The above elements all contribute towards the possibility of successful use with management overseeing, controlling and supporting all the significant areas. This could also warn project managers prior to the occurrence of issues and rather than concentrating on technical and financial issues, they can also examine other factors for successful adoption. With regards to senior management, the findings of this study will help direct the use of limited resources to major areas that would enhance the process of implementation. Evidence from the findings can be used by ERPBI stakeholders to keep abreast of firm performance and to increase the likelihood of successful ERPBI system implementation.

\section{Conclusion}

It is crucial to determine and confirm the determinants of ERPBI use and adoption particularly in the developing nations' context for effective IT resources usage. Literature dedicated to the subject is lacking, especially in Saudi Arabia. This underlies the importance of providing an in-depth insight into the principles of ERPBI in the developing nations in order to facilitate software suppliers and organizational benefits. This would help decision makers to design an appropriate ERPBI strategies, and software designers and suppliers to create and launch products/services that are capable of meeting the end-users' requirements. Shedding light on the factors and their relationship with ERPBI use success would also assist top management in minimizing losses through system use for enhanced cash flow, controlled 
expenses, headcount management and improved performance of employees, aligned operations in spend-supply chain, keeping abreast of financial performance of major projects, enhancement of customer relationships and reporting systems use that can eventually bring about the overall performance of the organization. The mentioned factors all contribute to the success use of system, supported by management oversight, control and support. This could also play a role of an indicator of issues arising - as opposed to focusing solely on technical and financial issues. As for senior management, the study findings will assist their appropriation of limited resources to the key areas that could enhance the adoption process. The findings can be utilized by stakeholders to be informed of the performance of the firm and to enhance the successful ERPBI adoption. The present work lays stress on the lack of studies in literature regarding ERPBI and its major role in supporting and improving organizational performance. The paper stressed on the limitations of previous studies dedicated to ERPBI usage and hence, it proposes an ERPBI model to guide the system's successful adoption among organizations. Based on the literature review, this study supports a relationship between the adoption of ERPBI and effective guidance of the study model.

To enrich the path for further research on ERPBI usage, some future works are suggested here. Based on the findings of this study, some research could be conducted based on the proposed research model. Academics and researchers interested in ERPBI could thus benefit from the output of the model in this study. Further research is needed to investigate the curvilinear effects, which affect the relationships among ERPBI factors and comparison between the tested theories.

\section{Acknowledgement}

We would like to thank Universiti Kebangsaan Malaysia for financial support through Grant GUP-2019-061 and DCP-2017-013/6.

\section{References}

Adamala, S., \& Cidrin, L. (2011). Key success factors in business intelligence.

Ahmad, M. M., \& Cuenca, R. P. (2013). Critical success factors for ERP implementation in SMEs. Robotics and computer-integrated manufacturing, 29(3), 104-111.

Ahmad, S., Ibrahim, S., \& Garba, S. (2015). Enterprise Resource Planning (ERP) Systems in Banking Industry: Implementations Approaches, Reasons for Failures and How to Avoid Them. Journal of Computer Sciences and Applications, 3(2), 29-32. 
Ajzen, I. (1991). The theory of planned behavior. Organizational behavior and human decision processes, 50(2), 179-211.

Al-Adwan, S. I. (2020). Investigating the Adoption of ERP Systems: A Perspective from Case Study in Jordan. Journal of Information Technology Research (JITR), 13(1), 96-117.

Aldossari, S., \& Mukhtar, U. A. (2018, June). Enterprise resource planning and business intelligence to enhance organizational performance in private sector of KSA: a preliminary review. In International Conference of Reliable Information and Communication Technology (pp. 343-352). Springer, Cham.

Al-Fawaeer, M., \& Al-Zu'bi, H. A. (2013). Investigating the link between enterprise resource planning (ERP) effectiveness and supply chain management. order (Mooheba \& et al, 2011), 5(13).

Al-Hudhaif, S. A. (2010). Measuring quality of Information System Services in manufacturing organizations in Riyadh. Economics and Administration, 24(1).

Al-Mobaideen, H. O. (2014). The Impact of Change Management on the Application Enterprise Resource Planning System (ERP) Effectiveness: Field Study in Jordan Bromine Company. Journal of Management Research, 6(4), 79-98.

Al-Mudimigh, A., Zairi, M., \& Al-Mashari, M. (2002). ERP implementation: An integrative methodology Towards the E-Society (pp. 549-560): Springer.

Al-Shamlan, H. M., \& Al-Mudimigh, A. S. (2011). The Chang management strategies and processes for successful ERP implementation: a case study of MADAR. International Journal of Computer Science, 8(2), 399-407.

Al Bar, A., Mohamed, E., Akhtar, M. K., \& Abuhashish, F. (2011). A preliminary review of implementing Enterprise Mobile Application in ERP environment. International Journal of Engineering \& Technology, 11(4), 77-82.

AlBar, A. M., \& Hoque, M. R. (2017). Factors affecting cloud ERP adoption in Saudi Arabia: An empirical study. Information Development, 0266666917735677.

Albu, C.-N., Albu, N., Dumitru, M., \& Dumitru, V. F. (2015). The impact of the interaction between context variables and enterprise resource planning systems on organizational performance: A case study from a transition economy. Information Systems Management, 32(3), 252-264.

Aldossari, S., \& Mukhtar, U. A. (2018). Enterprise resource planning and business intelligence to enhance organizational performance in private sector of KSA: a preliminary review. Paper presented at the International Conference of Reliable Information and Communication Technology.

Alhirz, H., \& Sajeev, A. (2015). Do cultural dimensions differentiate ERP acceptance? A study in the context of Saudi Arabia. Information Technology \& People, 28(1), 163-194. 
Ali, A. S. B., \& Money, W. H. (2005). A study of project management system acceptance. Paper presented at the System Sciences, 2005. HICSS'05. Proceedings of the 38th Annual Hawaii International Conference on.

Ali, M., Brooks, L., Alshawi, S., \& Papazafeiropoulou, A. (2006). Cultural Dimensions and CRM Systems Implications: A Preliminary Framework. Paper presented at the Proceedings of the Twelfth Americas Conference on Information Systems.

Almajali, D. A., Masa'deh, R. e., \& Tarhini, A. (2016). Antecedents of ERP systems implementation success: a study on Jordanian healthcare sector. Journal of Enterprise Information Management, 29(4), 549-565.

Almeida, J., Barros, M. J., \& Maravilhas-Lopes, S. (2020). A Business Intelligence Maturity Evaluation Model for Management Information Systems Departments Handbook of Research on Emerging Technologies for Effective Project Management (pp. 255-270): IGI Global.

Altamony, H., Al-Salti, Z., Gharaibeh, A., \& Elyas, T. (2016). The relationship between change management strategy and successful enterprise resource planning (ERP) implementations: A theoretical perspective. International Journal of Business Management and Economic Research, 7(4), 690-703.

Althonayan, M., \& Althonayan, A. (2017). E-government system evaluation: The case of users' performance using ERP systems in higher education. Transforming Government: People, Process and Policy, 11(3), 306-342.

Ammar, S., \& Mardini, G. H. (2020). Enterprise resource planning enabling segmental information reporting practices of UK-FTSE 100. Accounting \& Finance.

Annamalai, C., \& Ramayah, T. (2013). Does the organizational culture act as a moderator in Indian enterprise resource planning (ERP) projects? An empirical study. Journal of Manufacturing Technology Management, 24(4), 555-587.

Badewi, A., Shehab, E., Zeng, J., \& Mohamad, M. (2017). ERP Benefits Capability Framework: Orchestration Theory Perspective. Business Process Management Journal(just-accepted), 00-00.

Bandura, A. (1986). Social foundations of thought and action: A social cognitive theory: Englewood Cliffs, NJ, US: Prentice-Hall, Inc.

Barat, J. (1992). Scenario playing for critical success factor analysis. Journal of Information Technology, 7(1), 12-19.

Bargshady, G., Alipanah, F., Abdulrazzaq, A. W., \& Chukwunonso, F. (2014). Business Inteligence Technology Implimentation Readiness Factors. Jurnal Teknologi, 68(3), 7-12.

Bhattacharya, M., Wamba, S. F., \& Kamdjoug, J. R. K. (2019). Exploring the Determinants of ERP Adoption Intention: The Case of ERP-Enabled Emergency Service. International Journal of Technology Diffusion (IJTD), 10(4), 58-76. 
Bradford, M., Earp, J. B., \& Grabski, S. (2014). Centralized end-to-end identity and access management and ERP systems: A multi-case analysis using the Technology Organization Environment framework. International Journal of Accounting Information Systems, 15(2), 149-165.

Brancheau, J. C., \& Wetherbe, J. C. (1987). Key issues in information systems management. MIS quarterly, 23-45.

Braun, V., \& Clarke, V. (2006). Using thematic analysis in psychology. Qualitative research in psychology, 3(2), 77-101.

Brenner, M. E., Green, J., \& Camilli, G. (2006). Interviewing in educational research. Handbook of complementary methods in education research, 2.

Bullen, C. V., \& Rockart, J. F. (1981). A primer on critical success factors.

Chan, J. O., Abu-Khadra, H., \& Alramahi, N. (2011). ERP II readiness in jordanian industrial companies. Communications of the IIMA, 11(2), 5.

Chaudhry, M. S., Iffat, N., \& Safdar, M. (2016). Critical Failure Factors and Significance of Business Intelligence System on Decision Making in Pakistan. Journal of Statistics, 23(1).

Chen, H., Chiang, R. H., \& Storey, V. C. (2012). Business intelligence and analytics: from big data to big impact. MIS quarterly, 1165-1188.

Chou, D. C., Bindu Tripuramallu, H., \& Chou, A. Y. (2005). BI and ERP integration. Information Management \& Computer Security, 13(5), 340-349.

Chou, P. (2018). Workplace Social Support and Attitude toward Enterprise Resource Planning System: A Perspective of Organizational Change. International Journal of Information Systems and Social Change (IJISSC), 9(1), 58-76.

Creswell, J. W. (2013). Research design: Qualitative, quantitative, and mixed methods approaches: Sage publications.

Davis, F. D., Bagozzi, R. P., \& Warshaw, P. R. (1989). User acceptance of computer technology: a comparison of two theoretical models. Management science, 35(8), $982-$ 1003.

Davis, F. D., Bagozzi, R. P., \& Warshaw, P. R. (1992). Extrinsic and intrinsic motivation to use computers in the workplace. Journal of applied social psychology, 22(14), 1111-1132.

Delone, W. H., \& McLean, E. R. (2003). The DeLone and McLean model of information systems success: a ten-year update. Journal of management information systems, 19(4), 930 .

Drelichowski, L. (2012). Evaluation of the efficiency of integrated ERP systems and business intelligence tools based on the diagnostic cases in the MSE sector. Information Systems in Management, 1 . 
Dresner, H. (2008). The performance management revolution: Business results through insight and action: John Wiley \& Sons.

El Amrani, R., Sarkar, S., \& Truex, D. (2010). Examination of the Post-Implementation Role of Competency Centers in ERP and BI: An International/Cross Cultural Investigation. Paper presented at the Fifth Pre-ICIS workshop on ES Research, St Louis 2010.

Elbashir, M. Z., Collier, P. A., \& Davern, M. J. (2008). Measuring the effects of business intelligence systems: The relationship between business process and organizational performance. International Journal of Accounting Information Systems, 9(3), 135-153.

Erp, K. J., Gevers, J. M., Rispens, S., \& Demerouti, E. (2018). Empowering public service workers to face bystander conflict: Enhancing resources through a training intervention. Journal of Occupational and Organizational Psychology, 91(1), 84-109.

Esteves, J., \& Pastor, J. (2001). Enterprise resource planning systems research: an annotated bibliography. Communications of the association for information systems, 7(1), 8.

Fanning, K., \& Centers, D. P. (2013). Intelligent business process management: Hype or reality? Journal of Corporate Accounting \& Finance, 24(5), 9-14.

Finney, S., \& Corbett, M. (2007). ERP implementation: a compilation and analysis of critical success factors. Business Process Management Journal, 13(3), 329-347.

Fishbein, M. (1979). A theory of reasoned action: some applications and implications.

Françoise, O., Bourgault, M., \& Pellerin, R. (2009). ERP implementation through critical success factors' management. Business Process Management Journal, 15(3), 371-394.

Gazem, N., \& Rahman, A. A. (2015). Matrix for mapping ICT roles in small and medium enterprises with TRIZ inventive principles based on redesign service types. Journal Teknologi, 73(2), 67-75.

Global, E. (2010). Enterprise Resource Planning.

Goni, F. A., Chofreh, A. G., Mukhtar, M., Sahran, S., \& Shukor, S. A. (2012). Segments and elements influenced on ERP system implementation. Australian Journal of Basic and Applied Sciences, 6(10), 209-221.

Gorla, N. (2011). An assessment of information systems service quality using SERVQUAL+. ACM SIGMIS Database: the DATABASE for Advances in Information Systems, 42(3), 4670.

Harris, L. R., \& Brown, G. T. (2010). Mixing interview and questionnaire methods: Practical problems in aligning data.

Hartley, M., \& Seymour, L. (2015). Key success factors for implementing Business Intelligence in South African public sector organisations. Paper presented at the 9th IDIA Conference, IDIA2015. 
Hawari, A. a., \& Heeks, R. (2010). Explaining ERP failure in a developing country: a Jordanian case study. Journal of Enterprise Information Management, 23(2), 135-160.

Hawking, P., \& Sellitto, C. (2010a). Business Intelligence (BI) critical success factors. Paper presented at the 21st Australian Conference on Informafion Systems.

Hawking, P., \& Sellitto, C. (2010b). Critical success factors of business intelligence (BI) in an ERP systems environment: Citeseer.

Hawking, P., \& Sellitto, C. C. (2017). Developing an Effective Strategy for Organizational Business Intelligence Enterprise Information Systems and the Digitalization of Business Functions (pp. 222-237): IGI Global.

Hayes, J. (2014). The theory and practice of change management: Palgrave Macmillan.

Heinrich, R., Merkle, P., Henss, J., \& Paech, B. (2017). Integrating business process simulation and information system simulation for performance prediction. Software \& Systems Modeling, 16(1), 257-277.

Helmy, Y. M., Marie, M. I., \& Mosaad, S. M. (2012). An integrated ERP with web portal. Advanced Computing, 3(5), 1.

Holland, C. P., Light, B., \& Gibson, N. (1999). A critical success factors model for enterprise resource planning implementation. Paper presented at the Proceedings of the 7th European conference on information systems.

Hou, C.-K. (2014). A model for evaluating the potential impact of integrating ERP systems with BI systems on organisational performance: an empirical study of the semiconductor industry. International Journal of Technology, Policy and Management, 14(3), 250-270.

Hribar Rajterič, I. (2010). Overview of business intelligence maturity models. Management: Journal of Contemporary Management Issues, 15(1), 47-67.

Hsiao, S.-J., Li, Y.-C., Chen, Y.-L., \& Ko, H.-C. (2009). Critical factors for the adoption of mobile nursing information systems in Taiwan: the nursing department administrators' perspective. Journal of medical systems, 33(5), 369.

Huryk, L. A. (2010). Factors influencing nurses' attitudes towards healthcare information technology. Journal of Nursing Management, 18(5), 606-612.

Ince, H., Imamoglu, S. Z., Keskin, H., Akgun, A., \& Efe, M. N. (2013). The impact of ERP systems and supply chain management practices on firm performance: case of Turkish companies. Procedia-Social and Behavioral Sciences, 99, 1124-1133.

ISLAM NOFAL, M., \& YUSOF, Z. M. (2016). TAXONOMY FRAMEWORK OF ERP SUCCESS USAGE IN SMEs IN MIDDLE EAST REGION. Journal of Theoretical \& Applied Information Technology, 86(3). 
Jinno, H., Abe, H., \& Iizuka, K. (2017). Consideration of ERP Effectiveness: From the Perspective of ERP Implementation Policy and Operational Effectiveness. Information, $8(1), 14$.

Kasemsap, K. (2017). Mastering business process management and business intelligence in global business Organizational productivity and performance measurements using predictive modeling and analytics (pp. 192-212): IGI Global.

Khan, H. U., Awan, M. A., \& Ho, H. C. (2018). How do Chinese and Saudi customers perceive online service quality? A comparative study. The Journal of Business Inquiry, $13(2), 146-161$.

Khandelwal, V. K., \& Ferguson, J. R. (1999). Critical success factors (CSFs) and the growth of IT in selected geographic regions. Paper presented at the Systems Sciences, 1999. HICSS-32. Proceedings of the 32nd Annual Hawaii International Conference on.

Khandewal, V., \& Miller, J. (1992). Information system study. Opportunity Management Program.

Kock, N., Jenkins, A., \& Wellington, R. (1999). A field study of success and failure factors in asynchronous groupware supported process improvement groups. Business Process Management Journal, 5(3), 238-254.

Komba, M. M., \& Ngulube, P. (2015). Factors That Influence E-Government Adoption in Selected Districts of Tanzania. Paper presented at the International Conference on eBusiness, eCommerce, eManagement, eLearning and eGovernance.

Lacey, A., \& Luff, D. (2001). Trent Focus for Research and Development in Primary Health Care: An Introduction to Quality Research. Trent Focus: Nottingham.

Law, C. C., \& Ngai, E. W. (2007). ERP systems adoption: An exploratory study of the organizational factors and impacts of ERP success. Information \& Management, 44(4), 418-432.

Lawley, M., Summers, J., Koronios, A., \& Gardiner, M. (2001). Critical success factors for regional community portals: a preliminary model. ANZMAC, Massey, New Zealand, Massey University.

Lee, D., Lee, S. M., Olson, D. L., \& Hwan Chung, S. (2010). The effect of organizational support on ERP implementation. Industrial management \& data systems, 110(2), 269-283.

Ludwick, D. A., \& Doucette, J. (2009). Adopting electronic medical records in primary care: lessons learned from health information systems implementation experience in seven countries. International journal of medical informatics, 78(1), 22-31.

MacCarthy, B., \& Atthirawong, W. (2001). Critical factors in international location decisions: a Delphi study. Paper presented at the The proceedings of 12th Annual Meeting of the Production and Operations Management, March 30th-April 2nd. 
Mahmood, M. A., \& Mann, G. J. (1993). Measuring the organizational impact of information technology investment: an exploratory study. Journal of management information systems, 10(1), 97-122.

Mandal, P., \& Gunasekaran, A. (2003). Issues in implementing ERP: A case study. European Journal of Operational Research, 146(2), 274-283.

Masa'deh, R. e., Obeidat, B. Y., \& Tarhini, A. (2016). A Jordanian empirical study of the associations among transformational leadership, transactional leadership, knowledge sharing, job performance, and firm performance: A structural equation modelling approach. Journal of Management Development, 35(5), 681-705.

Mayeh, M., Ramayah, T., \& Mishra, A. (2016). The role of absorptive capacity, communication and trust in ERP adoption. Journal of Systems and Software, 119, 58-69.

Mexas, M. P., Quelhas, O. L. G., \& Costa, H. G. (2012). Prioritization of enterprise resource planning systems criteria: Focusing on construction industry. International Journal of Production Economics, 139(1), 340-350.

Miranda, M. Q., Farias, J. S., de Araújo Schwartz, C., \& de Almeida, J. P. L. (2016). Technology adoption in diffusion of innovations perspective: introduction of an ERP system in a non-profit organization. RAI Revista de Administração e Inovação, 13(1), 4857.

Mirbagheri, F. A., \& Khajavi, G. (2013). Impact of ERP Implementation at Malaysian SMEs: Analysis of Five Dimensions Benefit. International Journal of Enterprise Computing and Business Systems, 2(1).

Misra, S. C., Singh, V., Jha, N. K., \& Bisui, S. (2016). Modeling privacy issues in distributed enterprise resource planning systems. International Journal of Communication Systems, 29(2), 378-401.

Mohammed, F., Ibrahim, O., Nilashi, M., \& Alzurqa, E. (2017). Cloud computing adoption model for e-government implementation. Information Development, 33(3), 303-323.

Motaghian, H., Hassanzadeh, A., \& Moghadam, D. K. (2013). Factors affecting university instructors' adoption of web-based learning systems: Case study of Iran. Computers \& Education, 61, 158-167.

Muaadh, M. (2014). Records Management Initiative Framework for Supporting Decision Making Process in Higher Professional Education of Yemen. Paper presented at the SOFTAM Postgraduate Seminar, 20-21 Oct., Research Center for Software Technology \& Management, , Faculty of Information Science and Technology, FTSM.

Mukred, M., M Yusof, Z., Mokhtar, U. A., \& Abdul Manap, N. (2016). Electronic records management system adoption readiness framework for higher professional education institutions in Yemen. International Journal on Advanced Science, Engineering and Information Technology, 6(6), 804-811. 
Mukred, M., \& Yusof, Z. M. (2015). The Role of Electronic Records Management (ERM) for supporting Decision making Process in Yemeni Higher Professional Education (HPE): A Preliminary Review. Jurnal Teknologi, 73(2), 117-122.

Mukred, M., \& Yusof, Z. M. (2017). The DeLone-McLean Information System Success Model for Electronic Records Management System Adoption in Higher Professional Education Institutions of Yemen. Paper presented at the International Conference of Reliable Information and Communication Technology.

Mukred, M., \& Yusof, Z. M. (2018). The Performance of Educational Institutions Through the Electronic Records Management Systems: Factors Influencing Electronic Records Management System Adoption. International Journal of Information Technology Project Management (IJITPM), 9(3), 34-51.

Mukred, M., Yusof, Z. M., \& Alotaibi, F. M. (2019). Ensuring the Productivity of Higher Learning Institutions Through Electronic Records Management System (ERMS). IEEE Access, 7, 97343-97364.

Mukred, M., Yusof, Z. M., Alotaibi, F. M., Asma'Mokhtar, U., \& Fauzi, F. (2019). The key factors in adopting an electronic records management system (ERMS) in the educational sector: A UTAUT-based framework. IEEE Access, 7, 35963-35980.

Mukred, M., Yusof, Z. M., Asma'Mokhtar, U., \& Fauzi, F. (2018). A Framework for Electronic Records Management System Adoption in the Higher Professional Education: Individual, Technological and Environmental Factors. Paper presented at the International Conference of Reliable Information and Communication Technology.

Mukred, M., Yusof, Z. M., Mokhtar, U. A., \& Fauzi, F. (2018). Taxonomic framework for factors influencing ERMS adoption in organisations of higher professional education. Journal of Information Science, 0165551518783133.

Mukred, M., Yusof, Z. M., Noor, N. A. B. M., Kayode, B. K., \& Al-Duais, R. (2019). The Role of Cloud Electronic Records Management System (ERMS) Technology in the Competency of Educational Institutions. Paper presented at the International Conference of Reliable Information and Communication Technology.

Myers, M. D. (1997). Qualitative research in information systems. Management Information Systems Quarterly, 21(2), 241-242.

Nah, F. F.-H., Zuckweiler, K. M., \& Lee-Shang Lau, J. (2003). ERP implementation: chief information officers' perceptions of critical success factors. International journal of Human-computer Interaction, 16(1), 5-22.

Nasab, S. S., Jaryani, F., Selamat, H. B., \& Masrom, M. (2017). Critical success factors for business intelligence system implementation in public sector organisation. International Journal of Information Systems and Change Management, 9(1), 22-43.

Negash, S., \& Gray, P. (2008). Business intelligence Handbook on decision support systems 2 (pp. 175-193): Springer. 
Ngai, E. W., Law, C. C., \& Wat, F. K. (2008). Examining the critical success factors in the adoption of enterprise resource planning. Computers in industry, 59(6), 548-564.

NJERI, M. I. (2013). STRATEGIC MANAGEMENT PRACTICES AND PERFORMANCE OF LARGE PHARMACEUTICAL FIRMS IN KENYA. SCHOOL OF BUSINESS, UNIVERSITY OF NAIROBI.

Nofal, M. I., \& Yusof, Z. M. (2013). Integration of business intelligence and enterprise resource planning within organizations. Procedia Technology, 11, 658-665.

Nzuki, D. M., \& Okelo-Odongo, W. (2015). Adoption of Enterprise Resource Planning Systems in Kenya: A Case of Selected Manufacturing Firms in Nairobi Metropolitan.

O'Mahony, A., \& Doran, J. (2009). The changing role of management accountants; evidence from the implementation of ERP systems in large organisations. International Journal of Business and Management, 3(8), 109.

Olszak, C. M., \& Ziemba, E. (2007). Approach to Building and Implementing Business Intelligence Systems. Interdisciplinary Journal of Information, Knowledge, and Management, 2, 135-148.

Olszak, C. M., \& Ziemba, E. (2012). Critical success factors for implementing business intelligence systems in small and medium enterprises on the example of upper Silesia, Poland. Interdisciplinary Journal of Information, Knowledge, and Management, 7(12), 129-150.

Pan, M.-J., \& Jang, W.-Y. (2008). Determinants of the adoption of enterprise resource planning within the technology-organization-environment framework: Taiwan's communications industry. Journal of Computer Information Systems, 48(3), 94-102.

Parr, A., \& Shanks, G. (2000). A model of ERP project implementation. Journal of Information Technology, 15(4), 289-303.

Pérez-Mira, B. (2010). Validity of DeLone and McLean's Model of Information Systems success at the web site level of analysis.

Petter, S., DeLone, W., \& McLean, E. R. (2013). Information systems success: The quest for the independent variables. Journal of management information systems, 29(4), 7-62.

Picken, J. C. (2017). From founder to CEO: An entrepreneur's roadmap. Business Horizons, 60(1), 7-14.

Rajan, C. A., \& Baral, R. (2015). Adoption of ERP system: An empirical study of factors influencing the usage of ERP and its impact on end user. IIMB Management Review, 27(2), 105-117.

Ram, J., Corkindale, D., \& Wu, M.-L. (2013). Examining the role of system quality in ERP projects. Industrial management \& data systems, 113(3), 350-366. 
Ram, J., Wu, M.-L., \& Tagg, R. (2014). Competitive advantage from ERP projects: Examining the role of key implementation drivers. International Journal of Project Management, 32(4), 663-675.

Ramakrishnan, T., Jones, M. C., \& Sidorova, A. (2012). Factors influencing business intelligence (BI) data collection strategies: An empirical investigation. Decision support systems, 52(2), 486-496.

Richards, G., Yeoh, W., Chong, A. Y. L., \& Popovič, A. (2017). Business intelligence effectiveness and corporate performance management: An empirical analysis. Journal of Computer Information Systems, 1-9.

Rogers Everett, M. (1995). Diffusion of innovations. New York, 12.

Rouhani, S., \& Lecic, D. M. (2018). Business Intelligence Impacts on Design of Enterprise Systems Encyclopedia of Information Science and Technology, Fourth Edition (pp. 29322942): IGI Global.

Saleh, T., \& Thoumy, M. (2018). The impact of ERP systems on organizational performance: In Lebanese wholesale engineering companies. Paper presented at the Industrial Technology and Management (ICITM), 2018 7th International Conference on.

Samander, B. A., Siam, M. R., Basri, W. S., \& Hamed, A. A. (2017). ERP Acceptance in Airline Industry of Saudi Arabia with Mediating Effect of Job Security. International Journal, 11(2), 226-240.

Sanzogni, L., Whungsuriya, J., \& Gray, H. (2008). Corporate Struggle with ICT in Thailand: A Case Study. The Electronic Journal of Information Systems in Developing Countries, 34(1), 1-15.

Seethamraju, R. (2015). Barriers to the adoption of management accounting (MA) processes in enterprise resource planning (ERP) environments. Paper presented at the System Sciences (HICSS), 2015 48th Hawaii International Conference on.

Shang, S., \& Seddon, P. B. (2007). Managing process deficiencies with enterprise systems. Business Process Management Journal, 13(3), 405-416.

Singh, C. D., Singh, R., \& Kaur, H. (2017). Critical appraisal for implementation of ERP in manufacturing industry: Citeseer.

Taylor, S., \& Todd, P. (1995). Decomposition and crossover effects in the theory of planned behavior: A study of consumer adoption intentions. International journal of research in marketing, 12(2), 137-155.

Thompson, R. L., Higgins, C. A., \& Howell, J. M. (1991). Personal computing: toward a conceptual model of utilization. MIS quarterly, 125-143.

Tishler, A., Dvir, D., Shenhar, A., \& Lipovetsky, S. (1996). Identifying critical success factors in defense development projects: A multivariate analysis. Technological forecasting and social change, 51(2), 151-171. 
Velić, M., Padavić, I., \& Lovrić, Z. (2012). Model of the new sales planning optimization and sales force deployment ERP Business Intelligence module for direct sales of the products and services with temporal characteristics. Paper presented at the Information Technology Interfaces (ITI), Proceedings of the ITI 2012 34th International Conference on.

Venkatesh, V., Morris, M. G., Davis, G. B., \& Davis, F. D. (2003). User acceptance of information technology: Toward a unified view. MIS quarterly, 425-478.

Wamba, S. F., Kamdjoug, J. R. K., Akter, S., \& Carillo, K. (2018). ERP Adoption and Use in Production Research: An Archival Analysis and Future Research Directions. Paper presented at the Conference on e-Business, e-Services and e-Society.

Yeoh, W., \& Koronios, A. (2010). Critical success factors for business intelligence systems. Journal of Computer Information Systems, 50(3), 23-32.

Yeoh, W., \& Popovič, A. (2016). Extending the understanding of critical success factors for implementing business intelligence systems. Journal of the Association for Information Science and Technology, 67(1), 134-147.

Yusof, Z. M., Ab Aziz, M. J., Shatat, A. S. A., \& Saleh, A. (2013). The relationship between user engagement and business intelligence system effectiveness. World Applied Sciences Journal, 28(7), 978-984.

Zheng, Y., Zhao, K., \& Stylianou, A. (2013). The impacts of information quality and system quality on users' continuance intention in information-exchange virtual communities: An empirical investigation. Decision support systems, 56, 513-524.

Ziemba, E. (2013). Conceptual model of information technology support for prosumption. Paper presented at the Proceedings of the International Conference on Management, Leadership and Governance. 